\title{
Malabsorption syndrome observed in the common octopus Octopus vulgaris infected with Aggregata octopiana (Protista: Apicomplexa)
}

\author{
C. Gestal ${ }^{1, *}$, M. Páez de la Cadena $^{2}$, S. Pascual ${ }^{1}$ \\ ${ }^{1}$ Area de Parasitología, FEPMAR- PB2, and ${ }^{2}$ Area de Bioquímica y Biología Molecular, Grupo BB1, Facultad de Ciencias, \\ Universidad de Vigo, Aptdo. 874-36200 Vigo, Spain
}

\begin{abstract}
Octopus vulgaris infected with Aggregata octopiana were collected from an open-water culture system in the Ría of Aldán (NW Spain). Digestive tract infection values were determined with the use of a Neubauer chamber by counting the number of A. octopiana sporocysts. After determining enzyme activity values by the colorimetric Api-Zym system Biomerieux ${ }^{\circledR}$, one representative enzyme of glycosidases, peptid hydrolases and phosphoric hydrolases showing high activity was spectrophotometrically analysed. The enzymes were maltase and leucine-aminopeptidase (LAP) involved in the absorption process, and acid phosphatase, a lysosomic enzyme, respectively. Enzymatic activity of maltase and LAP decreased significantly, with increased sporocyst counts. However, acid phosphatase activity increased with severity of infection, indicating the presence of degradative enzymes from phagocytic cells in the infected area. A detrimental effect on gastrointestinal function may result from a decrease or malfunction of absorption enzymes. The results suggest a malabsorption syndrome resulting from parasitic infection.
\end{abstract}

KEY WORDS: Octopus vulgaris $\cdot$ Aggregata octopiana $\cdot$ Absorption enzymes $\cdot$ Maltase $\cdot$ Leucineaminopeptidase $\cdot$ Acid phosphatase $\cdot$ Lysosomic enzyme

\section{INTRODUCTION}

The common octopus Octopus vulgaris (Cephalopoda: Octopodidae) is an important species in world fisheries (Roper et al. 1984, Domain et al. 2000, Josupeit 2000), representing a major protein resource in most fish-eating countries (Guerra 1992, Quetglas et al. 1998). It has great potential for mariculture and it is a valuable experimental animal for biomedical and behavioural research (Hanlon \& Forsythe 1985).

Despite the importance of this species, little is known of the epizootiology and physiopathology of even its

*Present address: Grupo ECOBIOMAR, Instituto de Investigaciones Marinas (CSIC), Eduardo Cabello 6, 36208 Vigo, Spain. E-mail: cgestal@iim.csic.es most common parasitic diseases. Parasitic infection by the eimeriroin coccidian genus Aggregata (Protozoa: Apicomplexa) has been noted as the most important infectious agent in wild and cultured cephalopod stocks from Spanish-Atlantic waters (Pascual et al. 1996, Gestal 2000). Gestal et al. (1999b) described the ultrastructure of A. octopiana in Galician waters (NW Spain). Gametogony and sporogony stages of the parasite occur in the digestive tract of the common octopus, the definitive host. Asexual stages are present in a crustacean, possibly the shrimp Palaemon serratus, the intermediate host (Gestal 2000, Gestal et al. 2002). These authors also described the histopathological effects of $A$. octopiaua infections in the digestive tract of Octopus vulgaris. Although enteric coccidiosis is not believed to be the primary cause of death, severe 
Aggregata infection may weaken the octopus, making it more vulnerable to other biotic and abiotic stressors.

The caecum is the target organ for both trophically transmitted Aggregata infections and absorption in cephalopods (Boucaud-Camoud \& Boucher-Rodoni 1983, Hochberg 1990). Consequently, our paper addresses the impact of this enteric infection on the activities of absorption and lysosome enzymes in octopus caecum.

\section{MATERIALS AND METHODS}

Collection of specimens. A total of 24 common octopuses Octopus vulgaris was collected from an openwater culture system in the Ría de Aldán, Galicia, Spain (NE Atlantic Ocean: $42^{\circ} 15^{\prime}$ N, $8^{\circ} 48^{\prime} \mathrm{W}$ ). The culture system allowed for easy and available sampling, made it possible to standardise feeding parameters, and thus provided a sample of animals of similar size, grown in similar environmental conditions. To minimise stress, all transported animals were maintained at the laboratory in polyethylene culture tanks containing $200 \mathrm{l}$ of aerated and continuously flowing $\left(60 \mathrm{l} \mathrm{h}^{-1}\right)$ natural seawater at 18 to $20^{\circ} \mathrm{C}$ for $24 \mathrm{~h}$ before the experiments. All animals were sized (DML = dorsal mantle length) and weighed (TBW = total body weight) to calculate the $K$-Fulton condition index $[K=$ $\left.\left(\mathrm{TBW} / \mathrm{DML}^{3}\right) \times 100\right]$.

Preparation of crude extracts. The biochemical study of the enzymatic activities in the host caecum was conducted with excised tissue. The animals were primarily anaesthetised in a seawater:ethanol $70 \%$ ratio of $5: 1$. The caecum was removed and vigorously washed in $10 \mathrm{mM}$ homogenisation phosphate buffer, $\mathrm{pH}$ 7.0, and weighed, after removing the digestive tract. For the sporocyst count, host tissue extracts obtained from a portion of caecum was prepared by homogenisation in an electric tissue grinder (IKAUltraTurrax T-25) following standard procedure (Gestal et al. 1999a). The number of Aggregata octopiaua sporocysts was estimated in a Neubauer count chamber. Sporocyst concentration was expressed as the total number of sporocysts per $\mathrm{g}$ of caecum tissue (SG) and as the total number of sporocysts per whole caecum sample (TS).

Remaining caecal samples were sealed in aluminium foil and stored at $-80^{\circ} \mathrm{C}$ for further enzymatic assays. After thawing, a piece of tissue was weighed for all samples and ground in ice-cold homogenisation buffer with 15 strokes in a Potter Elvehjem homogeniser. The final concentration of each sample was adjusted to $0.05 \mathrm{~g} \mathrm{ml}^{-1}$ by adding homogenisation buffer. Aliquots of total tissue extracts were frozen at $-80^{\circ} \mathrm{C}$ until further processing.
Protein assay. Protein content of the crude tissue extracts was measured according to Bradford's method (1976) with bovine serum albumin as standard. Absorbance was measured at $595 \mathrm{~nm}$; values were expressed as mg of protein per mg of tissue.

Api-Zym system test. A total of 19 digestive enzymes (see Table 1) in crude extracts were tested semiquantitatively with the Api-Zym system Biomerieux ${ }^{\circledR}$ : $\alpha$-fucosidase, $\alpha$-mannosidase, $\alpha$ - and $\beta$-galactosidase, $\alpha$ - and $\beta$-glucosidase, $N$-acetyl- $\beta$-glucosaminidase, $\beta$-glucuronidase, acid phosphatase and phoshydrolase at $\mathrm{pH}$ 5.4, and chymotrypsin, trypsin, valine-aminopeptidase, cystine-aminopeptidase, leucine-aminopeptidase (LAP), lipase (C14), esterase/lipase (C8), esterase (C4), alkaline phosphatase at pH 6.5 to 8.5 . The extracts were diluted in distilled water to a protein content of $0.25 \mathrm{mg} \mathrm{ml}^{-1}$ and $65 \mu$ thereof were added to each microcupule on the test trays. The trays were incubated for $4 \mathrm{~h}$ at 35 to $38^{\circ} \mathrm{C}$ following the recommended procedure. Values from 0 to 5 corresponding to $0-\geq 40 \mathrm{nmol}$ of hydrolysed colorimetric substrate were assigned to each reaction, following a colour chart. Assays were run in duplicate.

Spectrophotometry. An enzyme representative of those groups which showed high activity in the ApiZym tests was spectrophotometrically analysed: an $\alpha$-D-glucosidase (maltase) and LAP involved in the absorption process, and acid phosphatase, a lysosomic enzyme. Based on the preliminary results of the ApiZym system, the most important but representative enzymes of glycosidases, peptid hydrolases and phosphoric hydrolases, were spectrophotometrically analysed to account for nutrient absorption and phagocytosis, respectively.

Maltase assay ( $\alpha$-D-glucose glucohydrolase EC 3.2.1.20). Maltase activity was measured in crude tissue extracts following the Messer \& Dahlquist (1966) method. Maltose standard was used as the enzymatic substrate at a concentration of $190 \mathrm{mg} \mathrm{ml}^{-1}$. A total of $40 \mu \mathrm{l}$ of enzymatic sample (dilution 1:4 in homogenisation buffer from the initial concentration) was incubated for $20 \mathrm{~min}$ at $37^{\circ} \mathrm{C}$ in the presence of $40 \mu \mathrm{l}$ of substrate dissolved in $0.1 \mathrm{M}$ maleate buffer, $\mathrm{pH}$ 6.0. The released glucose was determined using the enzymatic colorimetric test Spinreact using a Tris/glucose oxidase reagent. A total of $1.2 \mathrm{ml}$ of the reagent was added to the reaction mixture and incubated for $10 \mathrm{~min}$ at $37^{\circ} \mathrm{C}$. After incubation and before reading, samples were centrifuged for $2 \mathrm{~min}$ at $600 \times \mathrm{g}$. One unit (U) of maltase enzyme is defined as the amount required to hydrolyse $1 \mu \mathrm{mol}$ of maltose $\mathrm{min}^{-1}$ under optimal conditions of $\mathrm{pH}$ and temperature.

Acid phosphatase assay (EC 3.1.3.2). Acid phosphatase activity was measured using $p$-nitrophenilphosphate $16 \mathrm{mM}$ as standard substrate dissolved in 
sodium acetate buffer, $180 \mathrm{mM}$, pH 5.0. A mixture containing $0.2 \mathrm{ml}$ of the substrate and $50 \mu \mathrm{l}$ of enzymatic sample (1:3 dilution in homogenisation buffer of total extract tissue) was incubated for $25 \mathrm{~min}$ at $37^{\circ} \mathrm{C}$. The reaction was stopped by addition of $0.6 \mathrm{ml}$ of $0.25 \mathrm{M}$ $\mathrm{NaOH}$ and tubes were centrifuged at $700 \times g$ for 5 min. Released $p$-nitrophenol in the resulting supernatant was measured at $410 \mathrm{~nm}$ and the amount was calculated using a standard curve. One $U$ of acid phosphatase is defined as the amount required to hydrolyse 1 umol of $p$-nitrophenol $\mathrm{min}^{-1}$ under optimal conditions of $\mathrm{pH}$ and temperature.

LAP assay (EC 3.4.11.1). The assay was conducted with samples diluted 1:4 in homogenisation buffer. Aminopeptidase activity was assayed with L-leucine nitroanilide using nitroanilide as standard, following the procedures of Wachsmuth et al. (1966) and Boetius \& Felbeck (1995). L-leucine nitroanilide was dissolved in a $0.14 \mathrm{M} \mathrm{NaCl}$ solution with distilled water at $1 \mathrm{mg} \mathrm{ml}^{-1}$. A final substrate concentration of $1 \mathrm{mM}$ was obtained by mixing $50 \mu \mathrm{l}$ L-leucine nitroanilide with $25 \mu \mathrm{l}$ of a $10 \mathrm{mM} \mathrm{MnCl}_{2}$ solution, $25 \mu \mathrm{l}$ phosphate buffer ( $\mathrm{pH} 7.5$, $0.006 \mathrm{M}$ ) and $25 \mu \mathrm{l}$ diluted tissue extract. After $10 \mathrm{~min}$ of incubation at $37^{\circ} \mathrm{C}, 1 \mathrm{ml}$ of cold water was added to stop the reaction. Samples were centrifuged for $3 \mathrm{~min}$ at $600 \times g$ at $4^{\circ} \mathrm{C}$, and the release of nitroanilide was measured spectrophoto-metrically at $405 \mathrm{~nm}$. One U of LAP is defined as the amount required to hydrolyse $1 \mu \mathrm{mol}$ of $p$-nitrophenol $\mathrm{min}^{-1}$ under optimal conditions of $\mathrm{pH}$ and temperature.

Values of the enzyme activities were expressed as total activity (TA, expressed as $\mathrm{U}$ ) per mg of caecum tissue (TA $\mathrm{mg}^{-1}$ tissue).

Statistical analyses. Values of SG were separated into 2 groups, the first with low $(2000$ to $<100000)$ infection values, and the second with high (100000 to $3000000)$ infection values. The enzymatic activities expressed as TA mg ${ }^{-1}$ tissue are given as mean $+\mathrm{SD}$. Enzymatic activity data were compared with infection values measured at the infrapopulation level (Bush et al. 1997). The significance of the relationships between the enzymatic activities and sporocyst counts, and between the latter and the condition index, were determined by using regression models and analysis of variance (1-way ANOVA). The variables' enzymatic activity and sporocyst counts were logarithmically transformed $\left[\log _{10}(\mathrm{n}+1)\right]$ to reduce the variance, which helped to normalise the data (Elliot 1979). We have followed Weldon \& Slauson (1986) in recognising one important aspect of regression, the relative importance of the relationship (the proportion of variation associated with the relationship, as measured by $\mathrm{R}^{2}$ ). The limit of statistical significance was set at $p<0.05$. Data analysis was performed using the SPSSWIN 10.0 statistical software.
Table 1. Enzyme activities determined with the Api-Zym system. Units are standards used for the commercial test. Values $0-5$ correspond to $0-\geq 40 \mathrm{nmol}$ nitrophenyl released by each sample. -AP: -aminopeptidase

\begin{tabular}{|lc|}
\hline Enzyme & Range of values \\
\hline Glycosidases & \\
$\alpha$-fucosidase & $0-2$ \\
$\alpha$-mannosidase & 0 \\
$\beta$-galactosidase & $0-0.5$ \\
$\alpha$-galactosidase & 0 \\
$\beta$-glucosidase & 0 \\
$\alpha$-D-glucosidase & $0-0.5$ \\
$N$-acetyl- $\beta$-glucosaminidase & $2->5$ \\
glucuronidase & $0-0.5$ \\
Peptid hydrolases & \\
Chymiotrypsin & $0.5->5$ \\
Trypsin & 0 \\
Valine-AP & $1->5$ \\
Cystine-AP & $0.5-4$ \\
Leucine-AP & $>5$ \\
Ester hydrolases & \\
Lipase & $0-0.5$ \\
Esterase/lipase & $0.5-1.5$ \\
Esterase & $0.5-2$ \\
Phosphoric hydrolases & \\
Alkaline phosphatase & $1.5->5$ \\
Acid phosphatase & $>5$ \\
Naphthol phosphohydrolase & $>5$ \\
& \\
\hline
\end{tabular}

\section{RESULTS}

\section{Api-Zym system test}

Results from the Api-Zym system test provided an overview of the enzyme hydrolytic potentials of the common octopus (Table 1). The highest activities were found in LAP, acid phosphatase and naphthol phosphohydrolase. In all cases, $>40 \mathrm{nmol}$ of hydrolysed substrate was observed. Relatively high enzymatic activity was also observed for the alkaline phosphatase, peptide hydrolases (30 and $40 \mathrm{nmol}$ ), and glycosidases (between 5 and $20 \mathrm{nmol}$ for $\alpha$-fucosidase and $N$-acetyl- $\beta$-glucosaminidase).

\section{Spectrophotometry}

When the population was divided into 2 groups based on sporocyst concentration (Table 2), we observed that hosts with severe infection showed diminished activity in maltase and LAP, compared with that of hosts with a low number of sporocysts, whereas acid phosphatase showed increased activity. When comparing maltase and LAP activities in relation to the severity of the infection, the regression pattern indicated a significant statistical decrease in enzyme activities as 
Table 2. Mean and standard deviation (SD) of the enzymatic activities (expressed as total activity per mg of caecum tissue [TA $\mathrm{mg}^{-1}$ ]) for low infected (Group 1) and heavy infected (Group 2) host samples. SG: total number of sporocysts per $\mathrm{g}$ of caecum tissue; LAP: leucine-aminopepsidase

\begin{tabular}{|lcc|}
\hline Enzyme & $\begin{array}{c}\text { Group 1 } \\
(2000-<100000 \mathrm{SG}) \\
\left(\mathrm{TA} \mathrm{mg}^{-1}\right) \text { Mean } \pm \mathrm{SD}\end{array}$ & $\begin{array}{c}\text { Group 2 } \\
(100000-3000000 \mathrm{SG}) \\
\left(\mathrm{TA} \mathrm{mg}^{-1}\right) \text { Mean } \pm \mathrm{SD}\end{array}$ \\
\hline Maltase & $0.552 \pm 0.298$ & $0.414 \pm 0.077$ \\
LAP & $13.577 \pm 7.182$ & $8.157 \pm 4.144$ \\
Acid phosphatase & $3.061 \pm 1.353$ & $4.282 \pm 0.541$ \\
\hline
\end{tabular}

Table 3. Regression analyses for the relationship between enzymatic activities (expressed as total activity per mg of caecum tissue [TA $\left.\mathrm{mg}^{-1}\right]$ ), and number of sporocyst per whole caecum sample (TS)

\begin{tabular}{|lcrrrr|}
\hline Enzyme & $\mathrm{a}$ & $\mathrm{b}$ & $\mathrm{F}$ & $\mathrm{R}^{2}$ & $\mathrm{p}$ \\
\hline Maltase & 0.447100 & -0.162002 & 4.7391 & 0.1841 & 0.0410 \\
LAP & 1.725233 & -0.120938 & 6.6685 & 0.2410 & 0.0174 \\
Acid phosphatase & 0.107594 & 0.094239 & 14.2593 & 0.4044 & 0.0011 \\
\hline
\end{tabular}

Table 4. Regression analyses for the relationship between the $K$-Fulton condition index (CI) and the number of sporocysts per $\mathrm{g}$ of caecum tissue (SG) and the total number of sporocysts per whole caecum sample (TS)

\begin{tabular}{|cccccc|}
\hline CI & $\mathrm{a}$ & $\mathrm{b}$ & $F$ & $\mathrm{R}^{2}$ & $\mathrm{p}$ \\
\hline $\mathrm{SG}$ & 0.000640 & $-8.80827 \times 10^{-5}$ & 14.15000 & 0.4337 & 0.0012 \\
TS & 0.000472 & $-4.38984 \times 10^{-5}$ & 12.75794 & 0.2330 & 0.0009 \\
\hline
\end{tabular}

parasite count increased, whereas acid phosphatase showed an increasing pattern (Table 3). Moreover, a significant statistical relationship was found between the condition index and sporocyst counts. The condition index decreased as the variables SG and TS increased (Table 4).

No significant relationship $(F=1.09228, \mathrm{p}=0.3077)$ was found between protein concentration of tissue extracts and sporocyst counts for any sample.

\section{DISCUSSION}

In Galician waters, histopathological studies on infected caecum of the common octopus showed a high degree of invasiveness and pathogenicity of Aggregata octopiana (Gestal 2000). This intracellular parasite produces hypertrophy and degradation of infected cells with distension of the infected tissue area, causing rupture of the basal membrane and a breakdown of junctions among epithelial cells. Severe loss of epithelial cells and atrophy of mucosal folds occurred in affected intestine and caecum. In heavy infections, most infected host tissue was replaced by parasites. Loss of intestinal and caecum epithelium and destruction of the organ architecture was observed (Gestal 2000). Severe cellular change should result in detrimental effects on the gastrointestinal function, which could affect the individual and population fitness (Ferron \& Legget 1994).

We have applied biochemical analysis as a method for measuring fitness and to demonstrate the impact of Aggregata octopiana infection in the common octopus. We determined the levels of some enzymes using a colorimetric and semi-quantitative method. However, no differential patterns were easily discerned between subsamples related to the severity of infection. Subsequently we selected 2 enzymes involved in the intestinal absorption process and 1 lysosomic enzyme for quantitative analysis, comparing the possible relationship between infection severity (by counting the number of sporocysts) and the level of activity of these enzymes.

Using 2 different approaches we obtained similar results. A decrease in the absorption involved enzymes maltase and LAP, and an increase in the lysosomic-enzyme acid phosphatase related to the increased number of sporocysts. Since no variations were observed in the protein concentration related to the severity of infection, the observed differences in the activity of the enzymes are likely not due to a general decrease of total proteins.

Firstly, our results are interpreted as an overincrease of lysosomal activity, probably due to the massive presence of hemocytes and phagocytic cells attracted to the infected area. After phagocytosis, enzymes in phagocytic cells degrade foreign material according to the classical pathway of lysosomal digestion (Oubella et al. 1994).

Secondly, the obtained results also suggest that a malfunctioning of absorption enzymes is likely to occur in heavily infected octopus. Coccidians' metabolism produces considerable quantities of lactic acid, which may cause markedly lowered intestinal $\mathrm{pH}$ (Long 1973). Lowered intestinal $\mathrm{pH}$ causes denaturation of proteins, one of the factors responsible for disturbance in absorption of nutrients, and leakage of materials from the tissues by hampering deactivating-absorption 
enzymes (Long 1973). Maltase and LAP, which are active at $\mathrm{pH} \geq 7.0$, may be affected by the acidification of heavily infected caecum lumen, and consequently glucose and aminoacid absorption could be reduced. Important substrates in the diet of cephalopods, such as glucose and free aminoacids (Lee 1994), could not be digested and completely absorbed by caecal epithelial cells. Therefore, although substrates are available within the caecum lumen, their transport through the membrane is hindered by a failure in enzyme activities. This could result in a decrease of nutrient absorption and consequently in the deterioration of fitness of the common octopus. This argument is supported by a decrease in the $K$-Fulton condition index in more heavily infected octopus.

Similar results were described by Preston-Mafham \& Sykes (1970) and Long (1973) in birds and chickens infected with intestinal coccidia of the genus Eimeria. These authors described changes in the infected epithelium of absorption, producing a significant absorption decrease, a reduction of serum protein levels and body weight loss.

The results herein showed that although organ architecture may not be heavily histologically altered by parasitic infection, a detrimental effect on the gastrointestinal function may be produced because of decreased or malfunctioning absorption enzymes, which is designated as malabsorption syndrome.

Acknowledgements. We thank Dr. Angel Guerra (Grupo Ecobiomar, Instituto de Investigaciones Marinas de Vigo) for providing access to the octopus samples and for comments on earlier drafts of the paper. We also thank Dr. Ana Merino for helping with the enzymatic assay techniques. This work was partially supported by the Universidad de Vigo under Project No. 64102C021.

\section{LITERATURE CITED}

Boetius A, Felbeck H (1995) Digestive enzymes in marine invertebrates from hydrothermal vents and other reducing environments. Mar Biol 122:105-113

Boucaud-Camou E, Boucher-Rodoni R (1983) Feeding and digestion in cephalopods. In: Saleuddin SM, Wilbur KM (eds) The Mollusca, physiology, Vol 5, Part 2. Academic Press, London p 149-187

Bradford MA (1976) A rapid and sensitive method for the quantification of microgram quantities of protein utilizing the principle protein-dye binding. Anal Biochem 72: $248-254$

Bush AO, Lafferty KD, Lotz J, Shostak AW (1997) Parasitology meets ecology on its own terms: Margolis et al. revised. J Parasitol 83(4):575-583

Domain F, Jouffre D, Caverivière A (2000) Growth of Octopus vulgaris from tagging in Senegalese waters. J Mar Biol Assoc UK 80:699-705

Elliot JM (1979) Some methods for the analysis of samples of benthic invertebrates. Freshw Biol Assoc Sci Pub No. 25
Ferron A, Legget WC (1994) An appraisal of condition measures for marine fish larvae. Adv Mar Biol 30:217-303

Gestal C (2000) Epidemiología y patología de las coccidiosis en cefalópodos. PhD thesis, Universidad de Vigo

Gestal C, Abollo E, Pascual S (1999a) Evaluation of a method for isolation and purification of sporocysts of the cephalopod coccidian parasite Aggregata Frenzel, 1885 (Apicomplexa: Aggregatidae). Iberus 17(2):115-121

Gestal C, Pascual S, Corral L, Azevedo C (1999b) Ultrastructural aspects of the sporogony of Aggregata octopiana (Apicomplexa, Aggregatidae), a coccidian parasite of Octopus vulgaris (Mollusca, Cephalopoda) from NE Atlantic coast. Eur J Protistol 35:417-425

Gestal C, Guerra A, Pascual S, Azevedo C (2002) On the life cycle of Aggregata eberthi and observations on Aggregata octopiana (Apicomplexa, Aggregatidae) from NE Atlantic. Eur J Protistol 37:427-435

Guerra A (1992) Cephalopod resources of the world: a present day view. In: Nierentz JH (ed) The 2nd World Cephalopod Conference. Agra-Europe, London, p 1-14

Hanlon RT, Forsythe JW (1985) Advances in the laboratory culture of octopuses for biochemical research. Lab Anim Sci 35(1):33-40

Hochberg FG (1990) Diseases of Mollusca: Cephalopoda. Diseases caused by protistans and metazoans. In: Kinne O (ed) Diseases of marine annimals, Vol III. Biologische Anstalt Helgoland, Hamburg, p 47-227

Josupeit H (2000) Los mercados mundiales de cefalópodos. In: Ayala C (ed) Productos del mar $6^{\circ}$ Conferencia Internacional del Comercio de los Cefalópodos, Madrid, p 43-48

Lee PG (1994) Nutrition of cephalopods: fuelling the system. In: Pörtner HO, O'Dor RK, Macmillan DL (eds) Physiology of cephalopod molluscs. Gordon and Breach Publishers, Switzerland, p 35-51

Long PL (1973) Pathology and pathogenicity of coccidial infections. In: Hammond DM, Long PL (eds) The Coccidia. University Park Press, Baltimore, p 253-294

Messer M, Dahlquist A (1966) A one-step ultramicro method for the assay of intestinal disaccharidases. Anal Biochem 14:376-392

Oubella R, Paillard C, Maes P, Auffret M (1994) Changes in hemolymph parameters in the Manila clam Ruditapes phylippinarum (Mollusca, Bivalvia) following bacterial challenge. J Invertebr Pathol 64:33-38

Pascual S, Gestal C, Estévez J, Rodríguez H, Soto M, Abollo E, Arias C (1996) Parasites in commercially-exploited cephalopods (Mollusca, Cephalopoda) in Spain: an update perspective. Aquaculture 142:1-10

Preston-Mafham RA, Sykes AH (1970) Changes in body weight and intestinal absorption during infections with Eimeria acervulina in the chicken. Parasitology 61: 417-424

Quetglas A, Francesc A, Carbonell A, Merella P, Sánchez P (1998) Biology and fishery of Octopus vulgaris Cuvier, 1797, caught by trawlers in Mallorca (Balearic Sea, Western Mediterranean). Fish Res 36:237-249

Roper C, Sweeney MJ, Nauen CE (1984) FAO species catalogue, Vol 3. Cephalopods of the world. An annotated and illustrated catalogue of species of interest to fisheries. FAO Fisheries Synopsis 125, Rome

Wachsmuth ED, Fritze E, Pfleiderer G (1966) Marker enzymes and chemical assays for the analysis of subcellular fractions. Appendix 4. Biochemistry 5

Weldon CW, Slausson WL (1986) The intensity of competition versus its importance: an overlooked distinction. Q Rev Biol 61:23-44

Submitted: June 21, 2001; Accepted: April 14, 2002

Proofs received from author(s): July 11, 2002 